\title{
Ocean heat flux under Antarctic sea ice in the Bellingshausen and Amundsen Seas: two case studies
}

\author{
Stephen F. ACKLEY, Hongjie XIE, Elizabeth A. TICHENOR \\ Laboratory for Remote Sensing and Geoinformatics, Department of Geological Sciences, University of Texas at San Antonio, \\ San Antonio, TX, USA \\ E-mail: hongjie.xie@utsa.edu
}

\begin{abstract}
We examine the role of ocean heat flux (OHF) in Antarctic sea-ice growth and melt using data from autonomous ice mass-balance buoys deployed on pack ice in the Bellingshausen Sea and on fast ice in the Amundsen Sea during the spring/summer (October-December 2007) and summer/ autumn (February-March 2009) transitions, respectively. OHFs are derived using two methods that examine changes in (1) sub-ice ocean water properties $\left(\mathrm{OHF}_{1}\right)$ and (2) ice thickness $\left(\mathrm{OHF}_{2}\right)$, the latter only applying to thick snow-covered ice (i.e. a near-zero temperature gradient near the ice bottom). Good agreement is found between the time-averaged estimates of $\mathrm{OHF}_{1}$ and $\mathrm{OHF}_{2}$. Average OHF measured was $8 \pm 2 \mathrm{~W} \mathrm{~m}^{-2}$ under the pack ice and $17 \pm 2 \mathrm{~W} \mathrm{~m}^{-2}$ under the landfast ice. Some short-term OHF values $\left(\mathrm{OHF}_{1}\right)$ in both seas exceeded $55 \mathrm{~W} \mathrm{~m}^{-2}$. The spring OHF variations in the Bellingshausen Sea were periodic and controlled by semi-diurnal ice velocity fluctuations. Larger temperature fluctuations in the summer Amundsen Sea, originating from incursions of warm deep water masses, contributed to the OHF being twice as high as in the Bellingshausen Sea and also accounted for the irregular OHF variability there.
\end{abstract}

KEYWORDS: ice temperature, ice velocity, ice/ocean interactions, sea-ice growth and decay

\section{INTRODUCTION}

The ocean heat flux (OHF) is a function of heat storage within the upper ocean and of turbulent mixing in the boundary layer (McPhee, 1992). Sea-ice growth and melt are determined by the heat balance between the OHF and the conductive heat transfer through the overlying ice cover. In turn, melting or freezing of the ice cover affects the density profile of the surface water and can suppress or enhance vertical mixing. Low atmospheric temperatures drive sea-ice formation, while relatively high ocean temperatures that can limit ice growth are a principal cause of sea-ice melt in the Antarctic (Gordon and Huber, 1995). $\mathrm{OHF}$ to the under-ice surface can originate from warm deep water primarily in the Antarctic (Gordon and Huber, 1984, 1990, 1995; Martinson and lannuzzi, 1998; Muench and others, 2001; de Steur and others, 2007; Lei and others, 2010) or solar-heated surface water as observed in the Arctic (Perovich and others, 2007; Lei and others, 2014). Processes that redistribute heat from deep to surface water are convection and diffusion. Convection can be triggered by the interaction between currents and bottom topography in the eastern Weddell Sea (Muench and others, 2001), as well as by unstable density gradients caused by brine rejection during sea-ice freezing (Martinson and lannuzzi, 1998). In the ocean, turbulent eddies can provide local sources of heat. Drag between ice and the underlying ocean causes turbulence that then gives rise to heat exchange between ocean and ice if these heat sources are present. As the drift speed of ice relative to the ocean increases, the drag at the ice/water interface increases and also increases the heat transfer. These processes are enhanced in the Antarctic, where a weak pycnocline compared to that in the Arctic allows for greater exchange of heat from deep waters to surface waters (Gordon and Huber, 1984, 1990, 1995). Besides entrainment of warm water from below, at times when water temperature within leads is above the freezing point, solar radiation can be another source of heat added directly to the surface water through these open leads (Perovich and others, 2007).

While the thermodynamic feedback mechanisms at the ice/water interface can affect the thickness, extent and duration of ice cover in the Antarctic (Gordon and Huber, 1990, 1995), seasonal melt and freezing affects global ocean circulation by altering density profiles and contributing to the Thermohaline Circulation or 'global conveyor belt' (Brandon and others, 2010). Thus, it is important to understand ice-water interactions so they can be appropriately parameterized in both small- and largescale circulation and climate models. Several studies have estimated average OHF under Antarctic sea ice (e.g. Gordon and Huber, 1995; Lytle and Ackley, 1996; Muench and others, 2001; Hohmann and others, 2003; Ackley and others, 2008; McPhee, 2008). Short and dramatic flux events have also been observed (McPhee and others, 1999; Muench and others, 2001). However, more direct, instantaneous measurements are necessary to understand these details. Morison (1995), McPhee and others (1999) and de Steur and others (2007) measured instantaneous salinity and temperature values in the Weddell Sea so that highfrequency temporal variation in OHF, parameterized from these ocean properties, could be resolved. Similar work was also conducted in Prydz Bay, East Antarctica (Lei and others, 2010). The duration and frequency of occurrence of these short events are necessary to determine the longerterm effects on the average OHF. These studies, however, were dependent on time-series ocean physics information from autonomous drifters, previously done in the Antarctic only in a few locations (e.g. the Weddell Sea and Prydz Bay), but did not measure ice thickness changes or heat flux through the ice concurrently, so it was unclear what the 


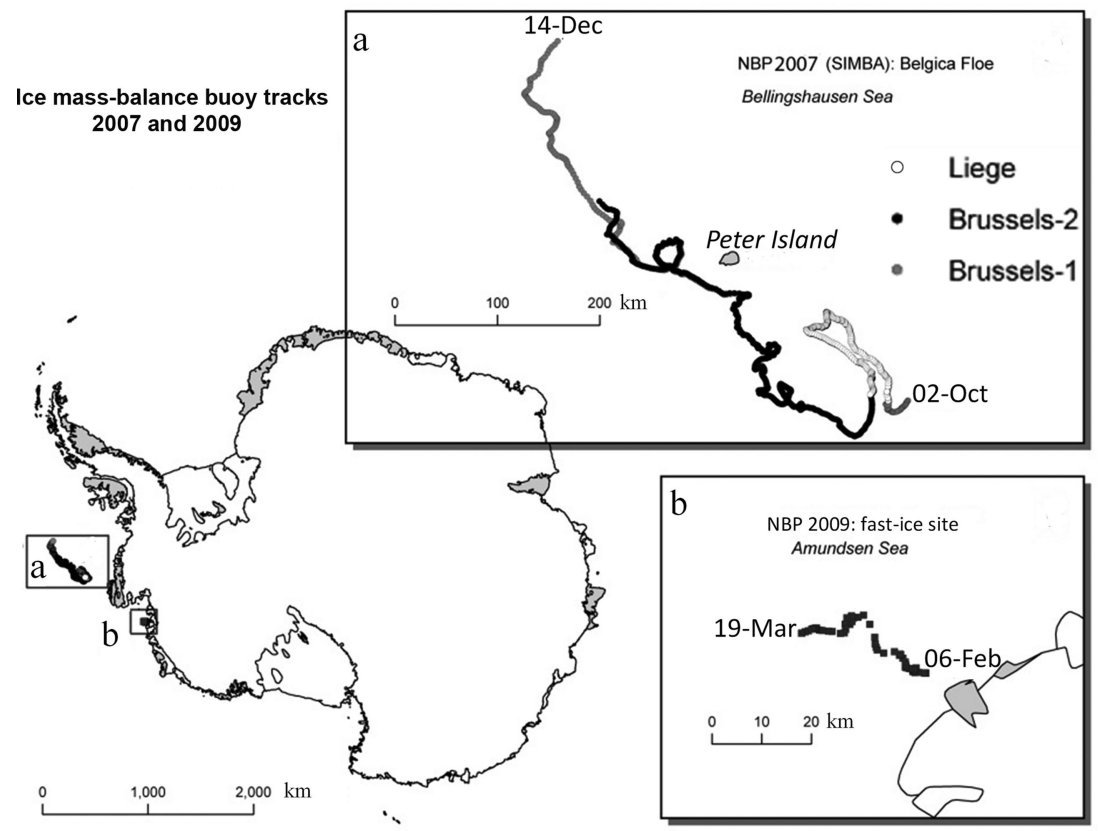

Fig. 1. IMB tracks (a) from October to December 2007, deployed during NBP 2007 (SIMBA) on a floe in the pack ice of the Bellingshausen Sea and (b) from February to March 2009, deployed during NBP 2009 on fast ice in the Amundsen Sea.

disposition of the OHF was and whether it resulted in direct ice melt or was conducted away and eventually vented to the atmosphere.

Our objective is to better resolve the interaction between ocean heat-flux processes and ice-cover processes by (1) determining OHF temporal variability at high frequencies from measured salinity, temperature and velocity in the ocean, (2) determining OHF independently at the same locations concurrently using ice-thickness and ice temperature changes, and (3) comparing the two methods and discussing the potential applications of the latter method.

\section{METHODS}

Autonomous drifters, ice mass-balance buoys (IMBs), with sensors mounted under pack ice in the Bellingshausen Sea and under fast ice in the Amundsen Sea of the Southern Ocean provided the data for this investigation.

\subsection{Instrumentation}

Figure 1 shows the deployment locations of the IMBs in the Bellingshausen and Amundsen Seas in October-December 2007 and February-March 2009, respectively. All IMBs used in the study were built by the US Army Cold Regions Research and Engineering Laboratory (CRREL) (Perovich and others, 2007). The three IMBs, named 'Brussels-1', 'Brussels2 ' and 'Liege', were deployed on a pack ice floe in the Bellingshausen Sea during the Sea Ice Mass Balance in the Antarctic (SIMBA) expedition (Lewis and others, 2011; Xie and others, 2011). The general snow and ice thicknesses were $0.08-0.14 \mathrm{~m}$ and $0.47-0.69 \mathrm{~m}$ at the Brussels sites, and $0.25-0.70 \mathrm{~m}$ and $0.90-1.20 \mathrm{~m}$ at the Liege site, respectively (Lewis and others, 2011). Before the icebreaker N.B. Palmer $(N B P)$ left the station, the Liege IMB was retrieved and was redeployed on the NBP 2009 cruise at a fast-ice site in the Amundsen Sea. Concurrently with the IMB data collection at the Amundsen Sea site, an ice-tethered profiler (ITP) was installed on the ice mass on which the IMB was positioned (within $50 \mathrm{~m}$ of each other) and collected water-column temperature and salinity profiles on a sampling schedule of one round-trip profile between 7 and $760 \mathrm{~m}$ depth each day. The ITP data were relayed by Iridium satellite and are available from the Ice-Tethered Profiler Program based at the Woods Hole Oceanographic Institution, MA, USA (http://www.whoi.edu/itp, ITP31; Toole and others, 2011). This site was stationary ('fast ice') from 6 February to 10 March 2009, detached from the land and drifted from 10 to 14 March 2009 (total distance of $60 \mathrm{~km}$ ), then stopped until drift resumed on 18 March 2009 and continued briefly through the end of transmission on 19 March 2009. Table 1 shows the parameters and times when data were collected for all stations. Each IMB measured geographic position (Garmin GPS16-HVS), surface-elevation changes (Campbell SR50A-L24 acoustic sensor mounted on a surface mast $\sim 2 \mathrm{~m}$ high), changes of the bottom ice surface (Benthos PSA916 sonar altimeter mounted on an underwater mast 1-2 m below the ice bottom, within a $14^{\circ}$ beamwidth and at $0.01 \mathrm{~m}$ resolution), and the vertical temperature profile that extended from the air, through the snow, ice and surface water to $1-2 \mathrm{~m}$ below the ice at $0.05-0.10 \mathrm{~m}$ intervals (YSI44033-BP thermistors, at $0.01^{\circ} \mathrm{C}$ resolution). The IMB at Brussels-1 also measured irradiance at the ice under-surface (not reported on here) (Satlantic OCR-504 4 channel underwater radiometer on an L-arm looking upward at $\sim 1.2 \mathrm{~m}$ depth), while the IMBs at Brussels-2 and the Amundsen Sea site were equipped to measure conductivity, temperature and depth (CTD) below the ice (Sea-Bird MicroCAT SBE 37-SI with pressure sensor mounted on an underwater mast $\sim 1.2 \mathrm{~m}$ below the ice bottom, at $0.002^{\circ} \mathrm{C}$ temperature resolution and 0.001 psu salinity resolution). All IMB sensors were autonomously sampled at 30 min intervals. Data were saved in a data logger (Campbell CR1000ST-SW-NC), transmitted and downloaded from the Advanced Research and Global Observation Satellite (ARGOS) system. The sensors and IMBs experienced life spans varying from 18 days (minimum) to 75 days (maximum). 
Table 1. Duration of IMB data records by data type and site

\begin{tabular}{|c|c|c|c|c|}
\hline \multirow[t]{2}{*}{ Data type } & \multicolumn{3}{|c|}{ NBP 07-09 (SIMBA) - 2007} & \multirow{2}{*}{$\begin{array}{l}\text { NBP 09-01 - } 2009 \\
\text { ITP/IMB fast-ice site }\end{array}$} \\
\hline & Brussels-1 & Brussels-2 & Liege & \\
\hline Position & 2 Oct to $14 \mathrm{Dec}$ & 12 Oct to 6 Dec & 4-22 Oct & 6 Feb to 19 Mar \\
\hline \multicolumn{5}{|l|}{ Atmosphere } \\
\hline Barometric pressure & SAA & SAA & SAA & 6 Feb to 19 Mar \\
\hline Air temperature & 2 Oct to $1 \mathrm{Nov}$ & SAA & SAA & SAA \\
\hline Temperature profile (air-snow-ice-water) & SAA & 12 Oct to 6 Dec & SAA & SAA \\
\hline \multicolumn{5}{|l|}{ Snow } \\
\hline Snow depth & SAA & 12 Oct to $1 \mathrm{Nov}$ & SAA & SAA \\
\hline Temperature profile (air-snow-ice-water) & SAA & 12 Oct to 6 Dec & SAA & SAA \\
\hline \multicolumn{5}{|l|}{ Ice } \\
\hline Ice thickness & SAA & 12 Oct to $1 \mathrm{Nov}$ & SAA & SAA \\
\hline Under-ice radiation $(442.50 \mathrm{~nm})$ & SAA & & - & - \\
\hline Under-ice radiation $(489.90 \mathrm{~nm})$ & SAA & - & - & - \\
\hline Under-ice radiation $(554.90 \mathrm{~nm})$ & SAA & - & - & - \\
\hline Depth of radiation measurements & 2 Oct to 3 Dec & - & - & - \\
\hline Temperature profile (air-snow-ice-water) & 2 Oct to $1 \mathrm{Nov}$ & 12 Oct to 6 Dec & SAA & SAA \\
\hline \multicolumn{5}{|l|}{ Water } \\
\hline Water conductivity & - & 12 Oct to $1 \mathrm{Nov}$ & - & SAA \\
\hline Water temperature & - & SAA & - & SAA \\
\hline Depth of CTD measurements & - & SAA & - & SAA \\
\hline Temperature profile (air-snow-ice-water) & SAA & 12 Oct to 6 Dec & SAA & SAA \\
\hline Water column temperature profile & - & - & - & 6 Feb to 20 Mar \\
\hline Water column salinity profile & - & - & - & SAA \\
\hline
\end{tabular}

Note: SAA denotes same as above.

\subsection{Parameterization of bulk OHF from ocean measurements}

Water temperature elevation (or temperature elevation hereafter), defined as the deviation of the sea-water temperature above the freezing point at the associated seawater salinity, has been identified as the measure of the available heat content in the mixed layer beneath the ice (e.g. Josberger, 1987; Morison and others, 1987; Wettlaufer and others, 1990; Wettlaufer, 1991; Omstedt and Wettlaufer, 1992). Morison and others (1987) parameterized the $\mathrm{OHF}$, using the temperature elevation, the friction velocity and a constant equal to the bulk heat transfer coefficient $\left(C_{\mathrm{H}}\right)$ divided by the density $(\rho)$ and specific heat $\left(c_{\mathrm{w}}\right)$ of sea water. Josberger (1987) showed the bulk heat transfer coefficient varied little over a wide range of ice-melting conditions. After Morison (1995) and McPhee and others (1999), $\left.C_{\mathrm{H}} \rho C_{\mathrm{W}} \sim 700 \mathrm{~W} \mathrm{~m}^{-2}{ }^{\circ} \mathrm{C}^{-1} \mathrm{~m}^{-1} \mathrm{~s}\right) \quad\left(C_{\mathrm{H}}=1.7 \times 10^{-4}\right.$, $\left.\rho=1024 \mathrm{~kg} \mathrm{~m}^{-3}, \quad C_{\mathrm{W}}=3980 \mathrm{~J} \mathrm{~kg}^{-1}{ }^{\circ} \mathrm{C}^{-1}\right)$, derived also from various experiments and modeling for melting sea ice in the Arctic (e.g. Josberger 1987; Morison and others, 1987; Omstedt and Wettlaufer, 1992), is used here. By direct comparison with turbulence measurements, McPhee and others (1999) found that this parameterization of heat flux from sea-water temperature deviation is in good agreement with measurements derived from turbulence measurements and also showed that friction velocity could be parameterized by ice-drift speed. Equation (1) (called $\mathrm{OHF}_{1}$ hereafter) with this value (700) is used to determine the $\mathrm{OHF}\left(\mathrm{W} \mathrm{m}^{-2}\right)$ :

$$
\mathrm{OHF}_{1}=u_{\mathrm{i}}\left(T-T_{\mathrm{f}}\right) \cdot 700
$$

where $u_{\mathrm{i}}\left(\mathrm{m} \mathrm{s}^{-1}\right)$ is the relative speed of the ice mass, $T\left({ }^{\circ} \mathrm{C}\right)$ is the temperature of the surface water and $T_{f}\left({ }^{\circ} \mathrm{C}\right)$ is the freezing point of the surface water

$$
\begin{aligned}
T_{\mathrm{f}}= & -0.057 S+\left(1.710523 \times 10^{-3}\right) S^{3 / 2} \\
& -\left(2.154996 \times 10^{-4}\right) S^{2}-\left(7.53 \times 10^{-4}\right) p
\end{aligned}
$$

where $S$ is the surface water salinity and $p$ (dbar) is pressure (Fujino and others, 1974).

Water salinities, computed from measurements of conductivity, temperature and pressure by a CTD measuring device suspended at $1.2 \mathrm{~m}$ below the ice (sea-water equation of state), were used to calculate the freezing points (Eqn (2)). The freezing point is subtracted from the measured temperature to determine the water temperature relative to its freezing point (i.e. the water temperature elevation), as a measure of the available heat content at the ice/water interface (McPhee and others, 1996; Sirevaag and others, 2010). However, the Bellingshausen Sea CTD data were confined to Brussels-2, and also ceased transmission on 1 November 2007, well before the end of the drift record on 6 December 2007 (Table 1). In order to extend the CTD sea-water temperature record, we instead use the thermistor records as a proxy. All of the IMBs were equipped with thermistors measuring surface water temperature under ice. The precision of the thermistors was, however, only $0.01^{\circ} \mathrm{C}$ (due to the loss of the last place by transmission of only an 8 -bit number) vs $0.002^{\circ} \mathrm{C}$ for the CTD temperature. Any single thermistor record was therefore too coarse in resolution to estimate variations in OHF. However, since there were 14-21 thermistors positioned in the uppermost 1.5$2 \mathrm{~m}$ of the surface water under ice, we are able to increase precision by averaging. The standard deviation is reduced to only $\pm 0.005^{\circ} \mathrm{C}$ for these combined records and therefore provides a more precise measure of temporal water 
temperature variations. Since the IMBs on the moving Belgica floe were in sufficiently close proximity (within a few hundred meters of each other) to reasonably assume that they were exposed to the same water masses, the average of the underwater thermistor measurements of water temperature from each of the IMBs is calibrated to the more accurate CTD measurements from Brussels-2 when both measurements were taken, and compared with that record. When corrected for a constant bias for each thermistor record, computation of the heat flux, shown later, gives $a<5 \%$ deviation from that computed from the CTD temperature.

Although salinity and pressure measurements are necessary to calculate the surface water freezing point (needed in Eqn (1)), the effect of the observed small salinity and pressure fluctuations on the freezing point as used in the OHF calculated from the CTD measurements is small compared to the effect of water temperature variations. Therefore, the average salinity and pressure measured by the CTD, up until 1 November 2007 when it failed, is used to estimate the surface water freezing point during the periods lacking a CTD record after 1 November 2007. The temperature above its freezing point using the average thermistor string records where CTD data are not available is then computed for the full length of the record in the Bellingshausen Sea and is used in estimating the OHF for the full duration (2 October to 6 December 2007) for all three sites in the Bellingshausen Sea. Errors in the OHF introduced by using the average freezing point, without accounting for the small fluctuations in freezing-point temperature with measured salinities, are within the $5 \%$ error introduced by using the thermistor temperatures instead of the CTD precision water temperature. Error propagation is further discussed in Section 4.1.

\subsection{OHF computed from ice freezing or melting}

When air temperatures are sufficiently low and the ice/water interface is not in thermal balance, heat may be conducted through the ice and snow, lost to the atmosphere, thereby establishing the potential for ice growth (Weeks and Ackley, 1986; Lytle and Ackley, 1996). During such conditions, from the steady-state heat balance, the OHF (Maykut, 1986) can be written as

$$
\mathrm{OHF}=k_{\mathrm{i}}(\partial T / \partial z)-\rho_{\mathrm{i}} L(\Delta t / A)
$$

where $k_{\mathrm{i}}$ is the thermal conductivity of ice (Eqn (4)) (Ono, 1968), $\partial T / \partial z\left({ }^{\circ} \mathrm{C} \mathrm{m}^{-1}\right)$ is the within-ice temperature gradient at the ice bottom surface, $\rho_{\mathrm{i}}$ is the density of the sea ice (assumed $920 \mathrm{~kg} \mathrm{~m}^{-3}$; Weeks and Ackley, 1986), $L$ is the latent heat of fusion (Eqn (5); Ono, 1968), $\Delta t\left(\mathrm{~m} \mathrm{~s}^{-1}\right)$ is the measured rate of ice thickness change and $A$ is the area $\left(A=1 \mathrm{~m}^{2}\right.$ in this context).

$$
\begin{gathered}
k_{\mathrm{i}}=k_{0}+0.13\left(S_{\mathrm{i}} / T_{\mathrm{i}}\right) \\
L=333394-2113 T_{\mathrm{i}}-114.2 S_{\mathrm{i}}+18040\left(S_{\mathrm{i}} / T_{\mathrm{i}}\right)
\end{gathered}
$$

where $k_{0}$ is the temperature-dependent pure ice thermal conductivity (however, a constant value of $2.1 \mathrm{~W} \mathrm{~m}^{-1}$ (Yen, 1981 ) is assumed in our calculations over the narrow temperature range used here), $S_{\mathrm{i}}$ is the salinity of the ice (used 5 according to ice-core records from Lewis and others, 2011) and $T_{\mathrm{i}}$ is the temperature of the ice at the measurement level.

Except for early March 2009 for the Amundsen Sea buoy, however, the temperature gradients near the ice bottom

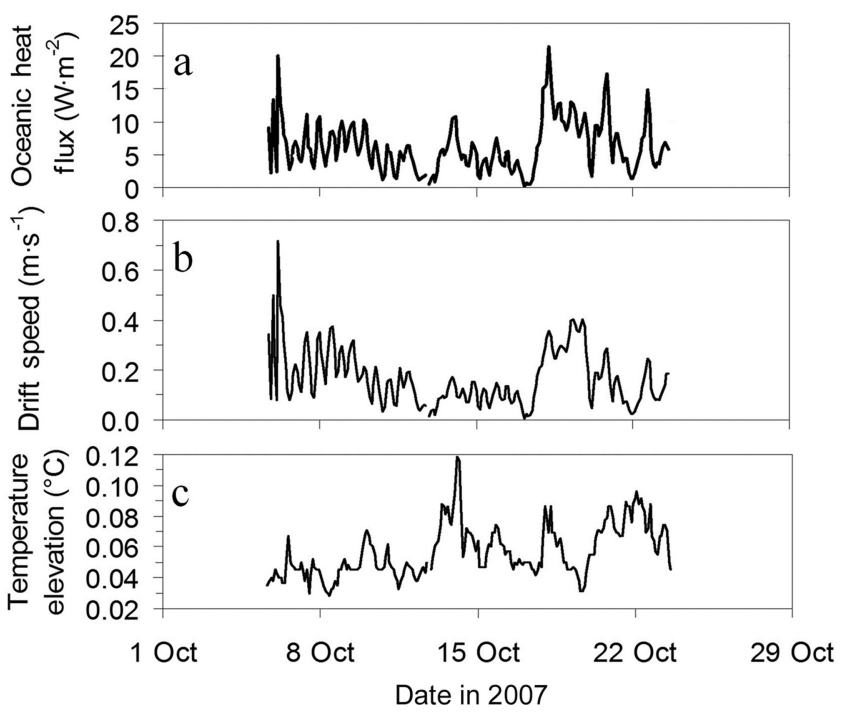

Fig. 2. Liege ocean heat flux from Eqn (1) $\left(\mathrm{OHF}_{1}\right.$ method; mean of $6 \mathrm{~W} \mathrm{~m}^{-2}$ ) (a), ice-floe drift speed (b) and water temperature elevation based on calibrated thermistor data (c), from 5 to 23 October 2007.

approached zero (Lewis and others, 2011), since surface air temperatures alternated between warm and cold episodes and the snow cover was consistently deep enough to insulate the bottom layers from the lowest air temperatures and therefore prevented heat conduction between ocean and atmosphere through the ice. Ice at the bottom was instead usually melting, under the influence of the OHF alone. Equation (3) can therefore be simplified, without the conductive term (called $\mathrm{OHF}_{2}$ hereafter):

$$
\mathrm{OHF}_{2}=\rho_{\mathrm{i}} L(\Delta t / A)
$$

The average OHF is used to melt the ice at a particular melt rate $\Delta t\left(\mathrm{~m} \mathrm{~s}^{-1}\right)$. The melt rate can be determined as the slope of the plot of ice thickness (net loss) with time.

The average OHF values from method $\mathrm{OHF}_{1}$ are compared with the average flux $\left(\mathrm{OHF}_{2}\right)$ derived from the ice melt rate in this study.

\section{RESULTS}

\subsection{Bellingshausen Sea}

\subsubsection{OHF derived from ocean measurements $\left(\mathrm{OH} F_{1}\right)$}

Figures 2-4 show the results from the Bellingshausen Sea IMBs in 2007 for Liege, Brussels-1 and Brussels-2, respectively. The average $\mathrm{OHF}_{1}$ measurements are in close agreement at 6, 7 and $8 \mathrm{Wm}^{-2}$, respectively, with the small differences accounted for by different record lengths from 2 October to 6 December 2007 for the three buoys (Table 1). Brussels-2 provides the longest record of OHF, which included a spike of $>55 \mathrm{~W} \mathrm{~m}^{-2}$ in the final days (December 2007). Ice-floe drift speeds as great as $0.6-0.7 \mathrm{~m} \mathrm{~s}^{-1}$ were measured. Water temperature elevations spiked to $\sim 0.13^{\circ} \mathrm{C}$ intermittently during October and November, and increased to $>0.24^{\circ} \mathrm{C}$ at the end of the Brussels- 2 record in early December 2007. These higher surface water temperatures and highest $\mathrm{OHF}_{1}$ in early December 2007 also coincided with $>0^{\circ} \mathrm{C}$ air temperatures (not shown). 

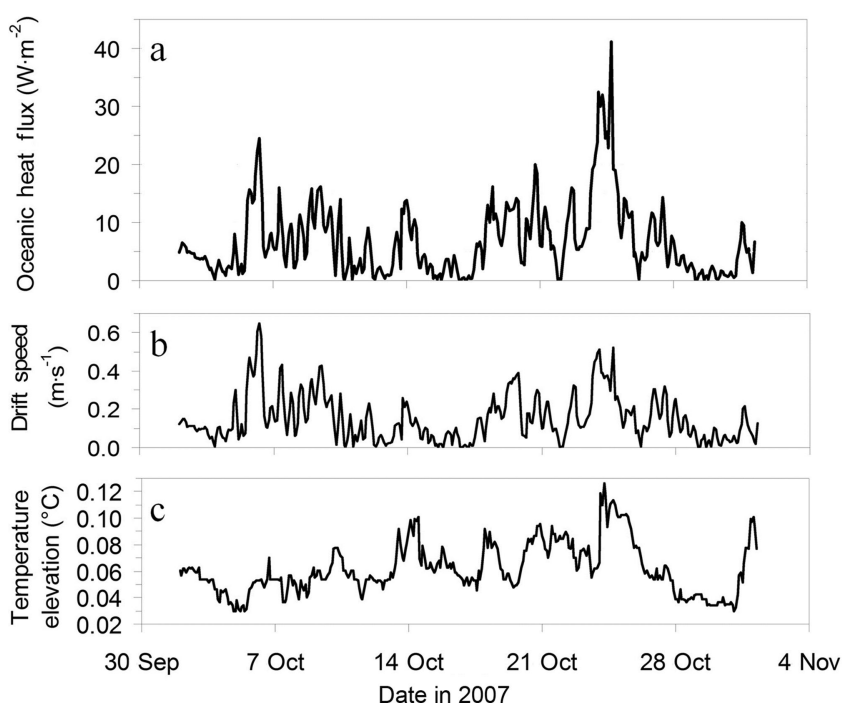

Fig. 3. Brussels- 1 OHF from Eqn (1) $\left(\mathrm{OHF}_{1}\right.$ method; mean of $7 \mathrm{~W} \mathrm{~m}^{-2}$ ) (a), ice-floe drift speed (b) and water temperature elevation based on calibrated thermistor data (c), from 2 October to 1 November 2007.

\subsection{2. $\mathrm{OHF}_{2}$ derived from ice melt rate}

The ice thickness time series (Fig. 5) shows ice thickness much larger at the Liege site than at the two Brussels sites. Under-ice photographs (http://www.utsa.edu/lrsg/ Antarctica/SIMBA/Pictures/album/Under\%20ice\%20photos/ index.html) indicate that the bottom surface of ice at Brussels-1 was relatively level, but scalloped (0.01-0.02 m variation) due to ice melt, while the under surface at Liege(a) had a complex topography resulting from deformation and melt events, with ice thickness spiking $0.5 \mathrm{~m}$, suggesting the upward-looking sonar periodically had returns from an

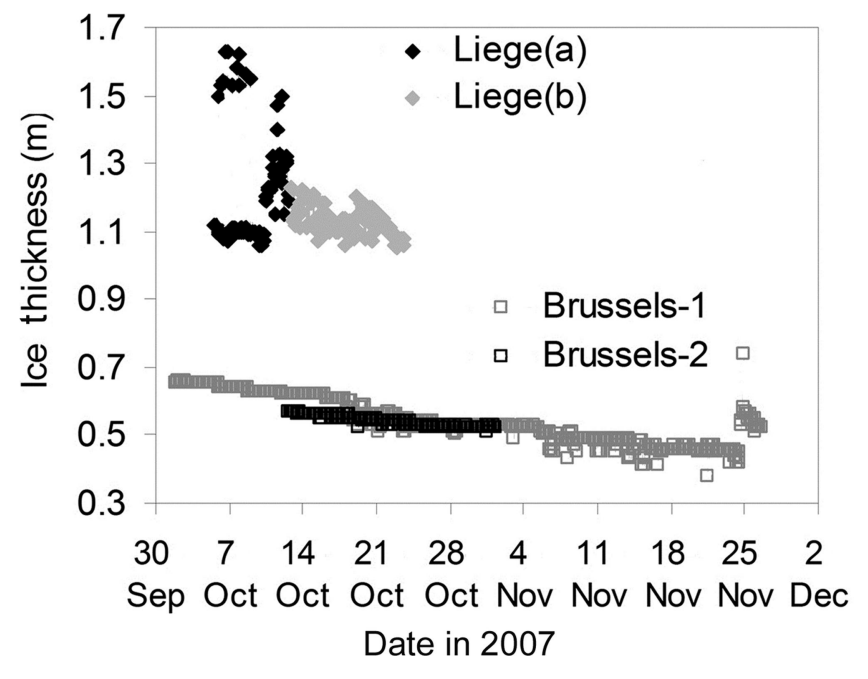

Fig. 5. Ice thickness time series from upward-looking sonar at the three IMB sites of the Belgica Floe, September to December 2007. The sensor at Liege(a) was relocated to Liege(b) on 12 October 2007.

irregular feature instead of the leveler ice. This phenomenon was also seen at an Arctic fast-ice site (Wang and others, 2013). The sensor was then relocated to Liege(b) on 12 October 2007, which largely reduced this noise in the ice thickness record. Therefore, only Liege(b) data are used to calculate the OHF using the $\mathrm{OHF}_{2}$ method. The top and bottom surfaces at the Brussels- 1 and Brussels-2 sites were uniform and similar (not shown). The average OHF derived from the ice melt rate $\left(\mathrm{OHF}_{2}\right)$ at Brussels-2 in the Bellingshausen Sea during 12-19 October 2007 was $\sim 8 \mathrm{~W} \mathrm{~m}^{-2}$ (Fig. 4a), which matches well with the mean $\mathrm{OHF}_{1}$ result from ocean temperature and salinity for the same time. The total derived $\mathrm{OHF}_{2}$ for Brussels- 1 is $12 \mathrm{~W} \mathrm{~m}^{-2}$ (2 October to 6 November 2007), larger than the $7 \mathrm{~W} \mathrm{~m}^{-2}$ from $\mathrm{OHF}_{1}$.

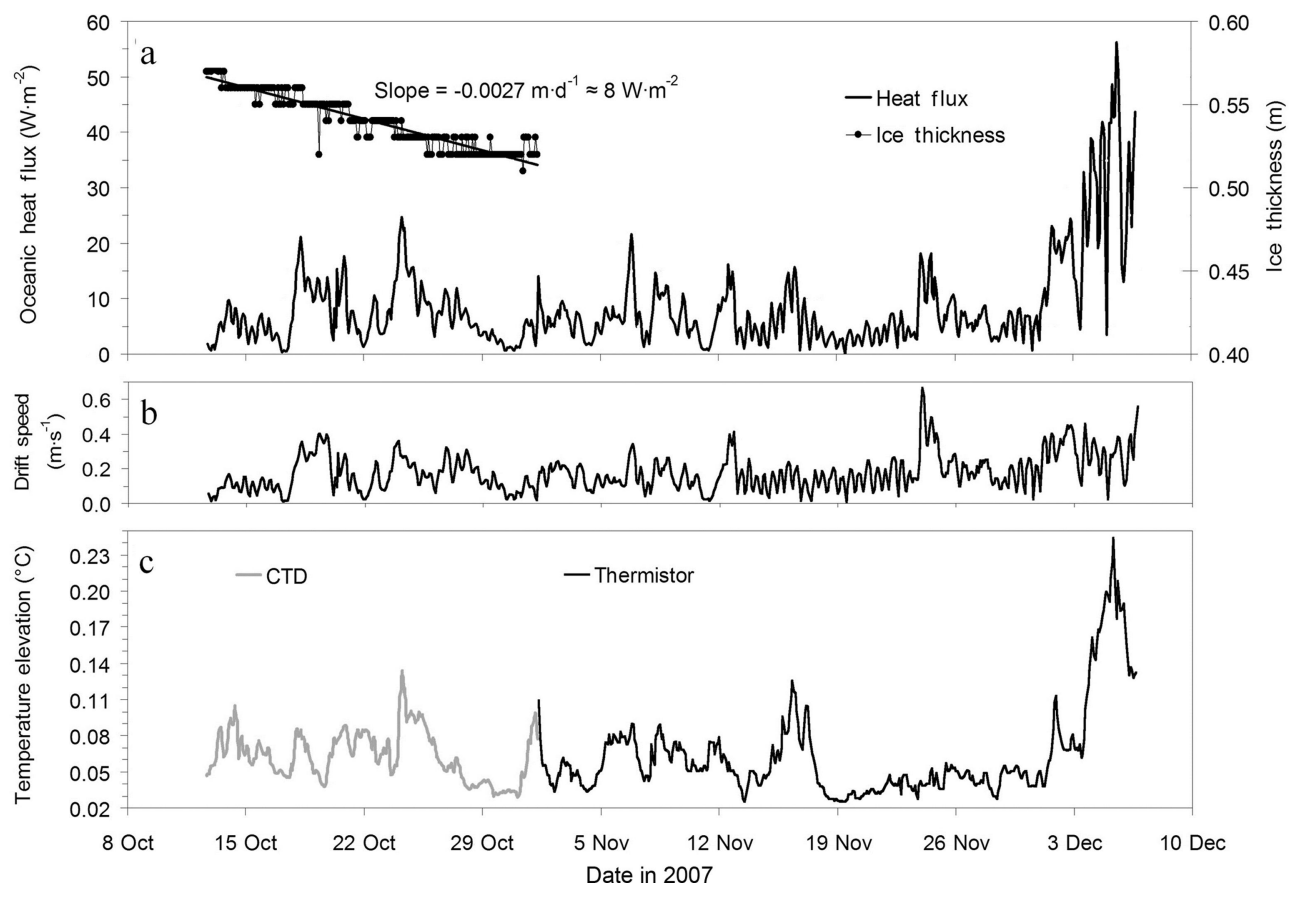

Fig. 4. Brussels-2 OHF from Eqn (1) $\left(\mathrm{OHF}_{1}\right)$ and ice thickness change (a), ice-floe drift speed (b) and water temperature elevation based on CTD (up to 1 November 2007) and calibrated thermistor data (after 1 November 2007) (c), from 12 October to 6 December 2007. The mean OHF of $8 \mathrm{~W} \mathrm{~m}^{-2}$ calculated from Eqn (6) $\left(\mathrm{OHF}_{2}\right)$ based on ice thickness time series (melt rate), also shown in (a), matched well with the mean OHF of $8 \mathrm{~W} \mathrm{~m}^{-2}$ using the $\mathrm{OHF}_{1}$ method for the same period, 12-29 October 2007. 


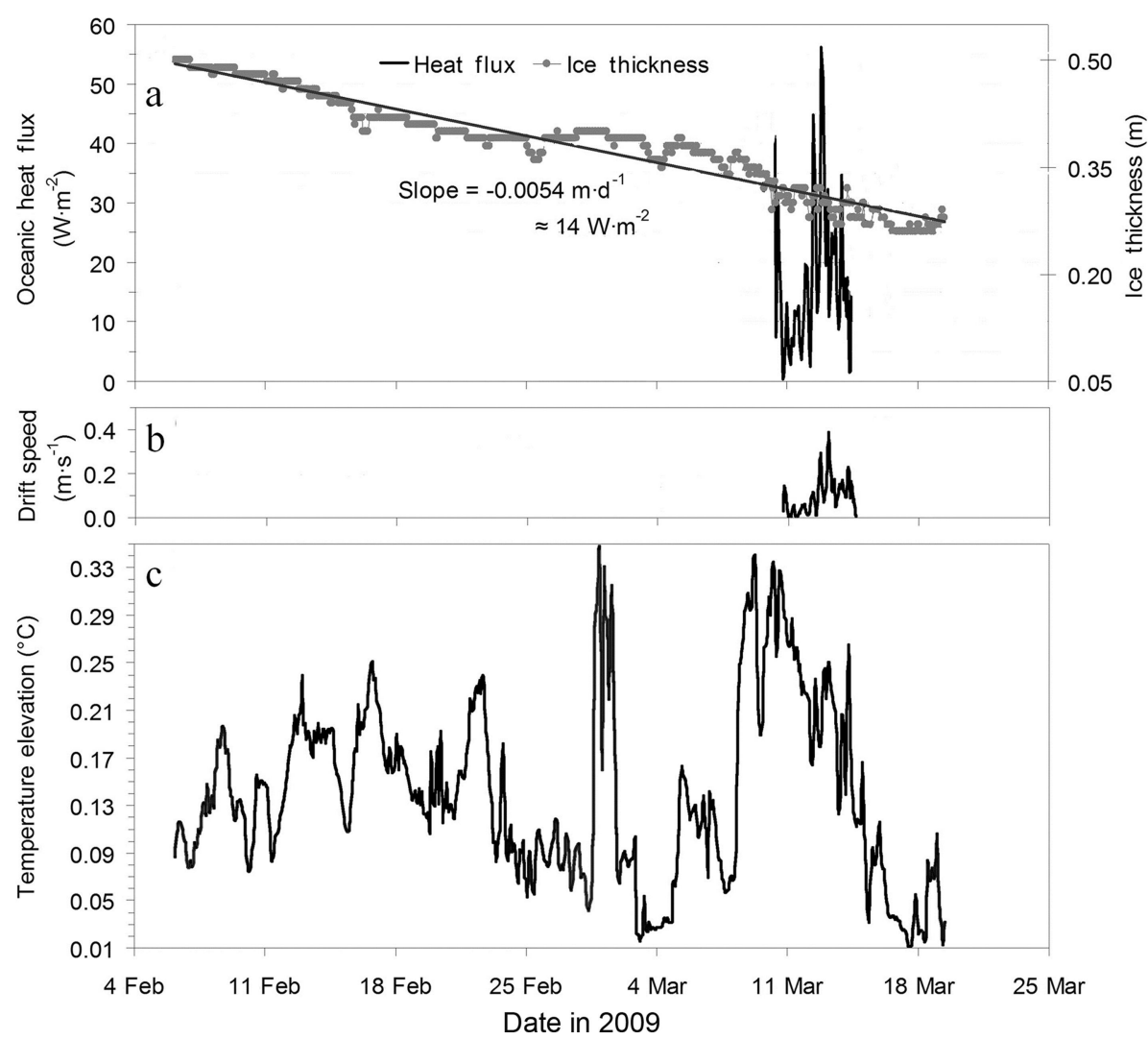

Fig. 6. Fast-ice site at Amundsen Sea (February to March 2009): (a) ocean heat flux $\left(\mathrm{OHF}_{2}\right)$ for the entire period derived from ice thickness melt rate, and instantaneous OHF $\left(\mathrm{OHF}_{1}\right)$ for the drift period (10-14 March 2009); (b) drift speed for the drift period; and (c) under-ice water temperature elevation based on calibrated thermistor data for the entire period.

This difference was probably due to the difference in time, since the latter was only from 2 October to 1 November 2007 (Fig. 4). The derived $\mathrm{OHF}_{2}$ for the Liege(b) site is $19 \mathrm{~W} \mathrm{~m}^{-2}(12-22$ October 2007), much larger than the $6 \mathrm{~W} \mathrm{~m}^{-2}\left(\mathrm{OHF}_{1}\right)$ for $5-23$ October 2007 (Fig. 4). This is a large difference and might be due to (1) difference in time and short overlap between the records, and (2) the rough bottom surface that resulted in larger error in ice thickness measurements as seen in Liege(b) (Fig. 5). Although the thickness variation in Liege(b) was much less than in Liege (a), the change of $0.2 \mathrm{~m}$ in 10 days (12-22 October 2007) in Liege(b) was still much larger than that seen from the Brussels sites. Therefore, the $19 \mathrm{~W} \mathrm{~m}^{-2}$ appears to be a much overestimated OHF value for the area, with rough bottom surface that caused large measurement variations in thickness change probably the primary cause.

\subsection{Amundsen Sea}

Since the ice was stationary most of the time at the Amundsen Sea site, the ice-drift speed (zero) cannot be used to estimate the friction velocity using the $\mathrm{OHF}_{1}$ method. Therefore, the $\mathrm{OHF}_{2}$ ice thickness change method is used. Figure 6a shows the full ice thickness time series, with a mean ice melt rate of $0.0054 \mathrm{~m} \mathrm{~d}^{-1}$, corresponding to an OHF of $14 \mathrm{~W} \mathrm{~m}^{-2}$. During short-lived events, the melt rate varies from 0.0049 to $0.0063 \mathrm{~m} \mathrm{~d}^{-1}$, corresponding to OHF of $12-16 \mathrm{~W} \mathrm{~m}^{-2}$, with a short exception where the $\mathrm{OHF}$ is almost 0 due to a melt rate close to 0 (not shown). Figure $6 \mathrm{c}$ shows the sea-water temperature elevation above its freezing point, which is overall much larger than that in the Bellingshausen Sea (Figs 2-4). For the drift from
10 to 14 March 2009, the OHF is also calculated using the $\mathrm{OHF}_{1}$ method (Fig. 6a). The maximum OHF was up to $55 \mathrm{~W} \mathrm{~m}^{-2}$, with a mean $\sim 17 \mathrm{Wm}^{-2}$. This mean value therefore generally agreed with the $\mathrm{OHF}_{2}\left(12-16 \mathrm{Wm}^{-2}\right)$ computed when the ice was stationary.

\section{DISCUSSION}

From an analytical perspective, of interest here is the validation of the bulk heat transfer parameterization, previously derived for the Arctic Ocean and Weddell Sea pack-ice regions (Josberger, 1987; Morison, 1995; McPhee and others, 1999) by an independent comparison, $\mathrm{OHF}_{1}$ computed using the parameterization, and $\mathrm{OHF}_{2}$ derived from ice-thickness changes only with concurrent measurements. It should be noted that the simplification of $\mathrm{OHF}_{2}$ with an assumption of near-zero temperature gradient near the bottom ice surface only works for the thick snowcovered ice, not for thin snow-covered ice. Since there have been only a few deployments with a CTD instrument on an $I M B$, this finding, that the average temperature measurements from thermistor strings corresponded well with the higher-precision CTD temperature measurements, is useful knowledge. This correspondence suggests that past deployments of thermistor strings can be reanalyzed for short-term OHF events in the western Weddell Sea (Lytle and Ackley, 1996) and Marguerite Bay on the western Antarctic Peninsula (Perovich and others, 2004), among several other areas in both polar regions where IMBs or nearsurface thermistor strings have been previously deployed, without an ice-moored CTD. These measurements may be 
particularly useful in seasons (autumn, winter, spring) when water salinity measurements are less important for deriving freezing-point temperatures as mixing processes and relatively low additions of fresh water from ice melt would have smaller effects on mixed layer salinity then.

\subsection{Error propagation on OHF calculations}

Close agreement is found between the average $\mathrm{OHF}_{2}$ derived from the smooth ice-thickness profile at Brussels-2 $\left(\sim 8 \mathrm{~W} \mathrm{~m}^{-2}\right)$ and the average of $\mathrm{OHF}_{1}$ derived from the salinity and temperature measured on the same IMB over the same time interval (also $8 \mathrm{~W} \mathrm{~m}^{-2}$ ) in the pack ice of the Bellingshausen Sea. The latter method using ocean temperature and conductivity values $\left(\mathrm{OHF}_{1}\right)$ can, however, show short-term temporal variability that is not detectable by the ice melt rate method $\left(\mathrm{OHF}_{2}\right)$ at the given data resolution.

Error in a single heat-flux value can arise from three sources: calculated velocity, measured temperature and estimated freezing-point temperature. The error in measured temperature of $\pm 0.01^{\circ} \mathrm{C}$ leads these, as the freezing point, determined by the salinity, does not vary much since the full range of salinity for these waters is $<1$ psu. Errors in velocity arise from differencing GPS positions that are closely spaced in time, so the error in an individual heat flux calculation can be up to an estimated $2 \mathrm{~W} \mathrm{~m}^{-2}$, or $25 \%$ of the average heat flux. However, we are still using a bulk parameterization of the heat flux, so it is only an approximation to the 'real' (turbulent) heat flux in any case, so in our view it is not so important to quantify the errors in an individual measurement. The time-averaged bulk parameterization of the heat flux, derived from ice velocity, ocean temperature and salinity, agrees well with the heat flux given by the change in ice thickness. The agreement suggests the individual measurement (bulk heat flux or ice thickness change) does not propagate but is instead smoothed out when time-averaged.

\subsection{Temporal variations of OHF correlate with wind}

The validated parameterization demonstrates the effect of ice-drift speed on calculating OHF in this location. Ice-drift speed can be highly variable, with rapid acceleration caused by intermittent changes in wind speed and direction (Geiger and others, 1998; Worby and others, 1998). Storm events and sharp wind fronts may therefore increase OHF under pack ice by means of added turbulent stress at the ice/ water interface (Gordon and Huber, 1984; McPhee, 1986; McPhee and others, 1987; Morison, 1995). The net drift of pack ice in the Bellingshausen Sea is largely wind-driven. However, studies (Geiger and others, 1998; Worby and others, 1998; Heil and others, 2008, 2009) also measured peaks in drift speed at $\sim 12-13$ hour intervals, which is approximately the semi-diurnal tide period and near the inertial period at the given latitudes. Therefore, while wind is a significant force on ice drift, the effects of inertial/tidal oscillations can dominate the drift pattern at semi-diurnal timescales (Geiger and others, 1998). Although the semidiurnal drift pattern is not as strong as seen in the Arctic summer sea ice, the drift speed itself in the Bellingshausen Sea is larger than in the Arctic $\left(0.17 \pm 0.08 \mathrm{~m} \mathrm{~s}^{-1}\right.$ ) (Xie and others, 2013). Consequently, where these variations noticeably affect drift speeds, particularly from mid-November to early December (Fig. 4b), they should also be expected to affect turbulent properties in the surface water beneath the ice and vertical shear across the pycnocline (McPhee, 1986; McPhee and others, 1987; Muench and others, 2001).
The roughly sinusoidal OHF shown for the Bellingshausen Sea is not seen at the fast-ice site in the Amundsen Sea due to zero drift speed during the stationary status. However, after the fast ice broke away from land, its drift pattern showed semi-diurnal peaks (Fig. 6b) (over a short record) similar to those seen in the Bellingshausen Sea. The drift speeds were well above the expected magnitude of tidal currents in the study area. Tidal speeds are only $\sim 0.01-$ $0.02 \mathrm{~m} \mathrm{~s}^{-1}$ during neap tides and $0.05 \mathrm{~m} \mathrm{~s}^{-1}$ during spring tides, based on the Circum-Antarctic Tidal Simulation version 2008b (CATS2008b) barotropic tide model, an update to the model described by Padman and others (2002). Therefore, wind-driven currents and inertial oscillations could have been the primary suppliers of energy to the turbulent mixing processes under the sea ice in the Amundsen Sea, similar to the Bellingshausen Sea.

However, seasonal difference is expected (Allison, 1979). Mean OHF of $6-8 \mathrm{~W} \mathrm{~m}^{-2}$ in the Bellingshausen Sea is much less than the $12-16 \mathrm{~W} \mathrm{~m}^{-2}$ in the Amundsen Sea. Indeed, even the presence of inertial oscillations in drift patterns is expected to vary seasonally, being especially evident during the melt season mostly because ice becomes too weak to dampen and resist the transmitted stress (McPhee, 1986).

Under the pack ice in the Bellingshausen Sea, OHF measurements peaked (up to $55 \mathrm{~W} \mathrm{~m}^{-2}$ ) in December after the ice floe had drifted into the marginal ice zone. It is possible that shortwave solar radiative heating of the surface water through opening leads contributed to the elevated surface water temperatures that contributed to the increased OHF at that time (Perovich and others, 2007), although the drift carrying the ice floe over a new water mass with different characteristics cannot be discounted (Gordon and Huber, 1995).

\subsection{Amundsen Sea: water stratification under fast ice}

The water stratification under fast ice is clearly visible (Fig. 7a), with the colder water found on the top of the $\sim 300 \mathrm{~m}$ column. The stratification of salinity is not so clear, although less saline water was mainly in the top $200 \mathrm{~m}$ (Fig. 7b). Comparisons between the CTD measurements at 1-2 $\mathrm{m}$ depth and the uppermost ITP CTD measurements at $8 \mathrm{~m}$ below the fast ice suggest, however, the very top surface water was colder and fresher (Fig. 7c and d) than that found below. As well, the CTD salinity measurements did not mirror the ITP salinity measurements at $8 \mathrm{~m}$ (Fig. $7 \mathrm{~d}$ ). In fact, in most cases, salinity spikes at $8 \mathrm{~m}$ are generally followed by salinity drops at 1-2 $\mathrm{m}$. We suspect that warm, saline water ascending from the deep warmer water below caused melt events which lowered the salinity in the uppermost 1 or $2 \mathrm{~m}$ of the surface water just under the ice. This may also account for the slightly lower temperatures measured directly below the ice. In particular, the large and wide salinity spike from 7 to 17 March 2009 seen in the ITP $8 \mathrm{~m}$ profile matches well with the increase in temperature at both $1-2 \mathrm{~m}$ and $8 \mathrm{~m}$, and the large decrease in salinity at 1-2 m, presumably due to ice melt. Persistent stratification may have been possible under the fast ice because drift was not contributing to turbulent mixing. Furthermore, a smooth ice-thickness time series measured by the sonar pinger (Fig. 6a) indicates that the under-ice surface was relatively level, perhaps also enhancing the stratification (McPhee, 1986). When the ice mass broke away and began to drift (18-19 March 2009), both the temperature and salinity values in the upper $10 \mathrm{~m}$ from the two sensors began to 

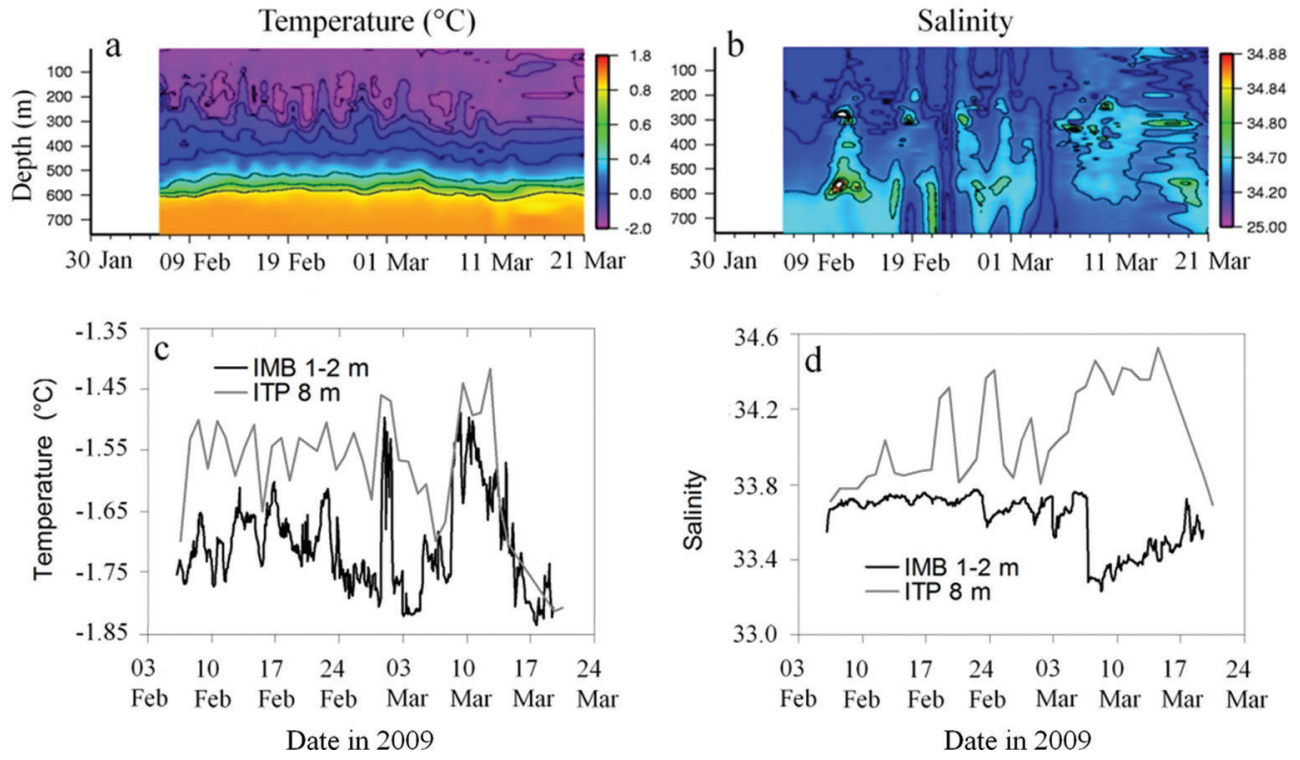

Fig. 7. ITP31 temperature profile (a) and salinity profile (b) by Julian day in 2009 at the fast-ice site in the Amundsen Sea. (c, d) Temperature (c) and salinity $(\mathrm{d})$ measurements at the uppermost ITP (8 $\mathrm{m}$ depth) with the corresponding IMB's CTD measurements positioned at 1-2 $\mathrm{m}$ depth.

converge (Fig. 7c and d), suggesting the water was mixing rather than remaining stratified.

Another factor that may have led to changing surface water stratification in March was possible ice growth, rather than melt, during the final 2 days of the record, as indicated by small positive ice thickness changes (Fig. 6a). Moreover, at the end of the record the required conditions for ice growth were measured by a bottom temperature gradient within the ice, conducting heat away from the previously isothermal bottom layer (Allison, 1981; Maykut, 1986). Figure 8 clearly shows that the bottom four depths $(-0.25,-0.35,-0.40$ and $-0.50 \mathrm{~m}$ ) of the ice were mostly isothermal, with temperature around $-1.7^{\circ} \mathrm{C}$, and were gradually melted away, with the first bottom $(-50 \mathrm{~m})$ on 15 February (melted away), the second bottom $(-40 \mathrm{~m})$ on 9 March and the third bottom $(-0.35 \mathrm{~m})$ on 15 March. After 15 March, the fourth bottom was at $-0.25 \mathrm{~m}$ and was once at the isothermal status with the $-0.20 \mathrm{~m}$ for $\sim 2$ days. But this isothermal status was rapidly broken on 17 March. A clear temperature gradient between the fourth bottom $\left(-0.25 \mathrm{~m}, \sim-2^{\circ} \mathrm{C}\right.$, at freezing point) and above $\left(-0.2 \mathrm{~m}, \sim-3^{\circ} \mathrm{C}\right.$ or smaller, below freezing point) then clearly appeared, favorable for ice growth, continuing for the next 2 days, 18 and 19 March.

Therefore, the end of under-ice melt and onset of ice growth marked the seasonal shift to autumn conditions in the under-ice water regime, lagging cold air temperature changes in the region by only a few days since the ice was $\sim 0.25 \mathrm{~m}$ thick at this time. Moreover, as sea ice freezes, the winter pycnocline is destabilized by brine-initiated convection so that deep water is then more susceptible to entrainment (Gordon and Huber, 1984). For example, brine rejection from rapidly growing ice was observed in March (Allison, 1981), so brine rejection during freezing may have led to the onset of high convective heat flux that was measured in the Amundsen Sea near the end of the record (Fig. 7c). The convergence of temperature and salinity values measured at 1-2 $\mathrm{m}$ depth from the IMB and $8 \mathrm{~m}$ depth from the ITP (Fig. 7c and d) is also consistent with mixing initiated by brine rejection during ice growth in the last few days of the record.
Unlike the Amundsen Sea summer, temperature and salinity time series at depth below the pack ice in the Bellingshausen Sea during spring, also collected from shipbased CTD casts of the SIMBA experiment, did not indicate uppermost surface water stratification under the drifting pack ice and generally showed a 'well-mixed' winter mixed layer with fairly uniform temperature and salinity, down to depths $>50 \mathrm{~m}$ (Lewis and others, 2011). One possibility is that the turbulent stress caused by drifting pack ice over a large area may have eroded the potential for uppermost surface water stratification caused by limited melt processes under the pack ice. Brine rejection below the ice was also observed by underwater photos (http://www.utsa.edu/lrsg/ Antarctica/SIMBA/Pictures/album/Under\%20ice\%20photos/)

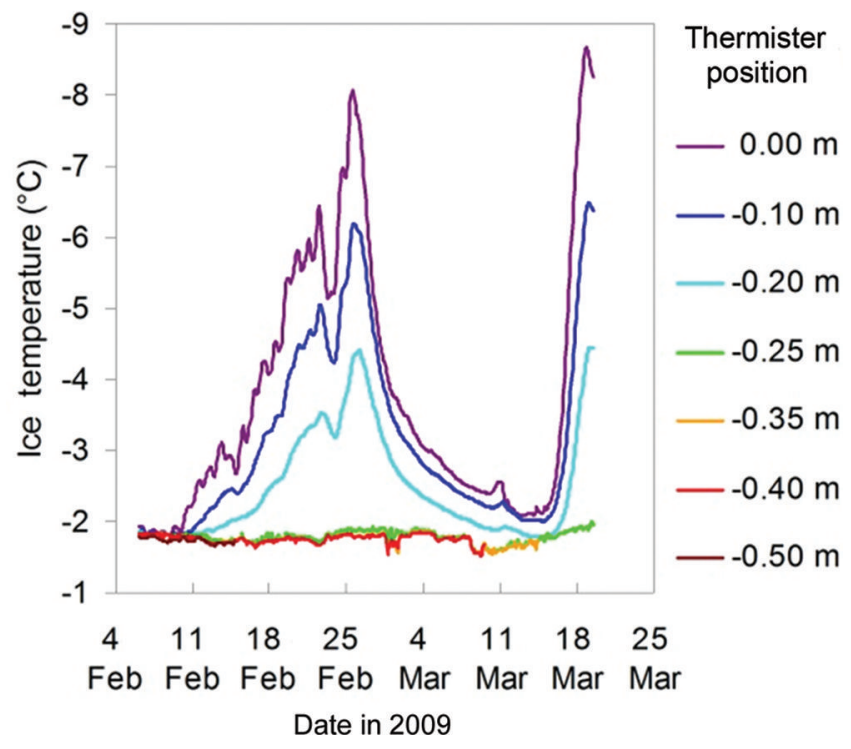

Fig. 8. Temperature gradient within the ice measured by a fixed thermistor string at the fast-ice site in the Amundsen Sea, February to March 2009. The vertical positions of the thermistors are referenced relative to the snow/ice interface at $0.00 \mathrm{~m}$ (the lowest temperature time series on the top, air/snow interface). 
Table 2. Under-ice ocean heat flux (OHF) estimates determined by various studies in the Southern Ocean

Study

$$
\text { Season }
$$

$$
\begin{array}{cc}
\text { Ave. } & \text { Max. } \\
\text { OHF } & \text { OHF } \\
\mathrm{W} \mathrm{m}^{-2} & \mathrm{~W} \mathrm{~m}^{-2}
\end{array}
$$

\begin{tabular}{|c|c|c|c|}
\hline & Fast ice & & \\
\hline Amundsen Sea & & & \\
\hline This study & Feb-Mar 2009 & 17-19 & 56 \\
\hline$y d z$ Bay & & & \\
\hline Lei and others (2010) & Apr-Dec 2006 & 5.6 & 24 \\
\hline & Pack ice & & \\
\hline ellingshausen Sea & & & \\
\hline his study & Oct-Dec 2007 & 8 & 56 \\
\hline 'eddell Sea & & & \\
\hline Lytle and Ackley (1996) & Feb-Jun 1992 & $7 \pm 2$ & 12 \\
\hline Robertson and others (1995) & Feb-Jun 1992 & 1.7 & 15 \\
\hline Sirevaag and others (2010) & Aug 2005 & 14,28 & 27,82 \\
\hline Morison (1995) & Jul-Dec 1994 & 20 & $>150$ \\
\hline Muench and others (2001) & Jul-Sep 1994 & 25 & $>100$ \\
\hline McPhee and others (1999) & Jul-Sep 1994 & 23 & - \\
\hline Gordon and Huber (1990) & Jul-Sep 1986 & 41 & - \\
\hline Hohmann and others (2003) & Winter 1986 and 1994 & $14 \pm 4$ & - \\
\hline & Annual & $6 \pm 4$ & - \\
\hline ordon and Huber (1995) & Austral spring 1989 & $38 \pm 15$ & 58 \\
\hline cPhee and Martinson (1994) & & & 15 \\
\hline ordon and others (1984) & Ice-covered & $20-25$ & - \\
\hline
\end{tabular}

at the IMB sites, caused by freezing in the upper layers (only) of the ice during cold episodes, and new ice growth was also observed in lead areas nearby during the ship drift. Therefore, freshening by melt may have been balanced by salinization from this brine rejection and coincident growth of thin ice during spring 2007 in the Bellingshausen Sea.

\subsection{Comparison with previous findings}

Several previous studies have reported a large range of $\mathrm{OHF}$ in the Weddell Sea, $1.7-41 \mathrm{~W} \mathrm{~m}^{-2}$ on average, with a maximum value of $>150 \mathrm{~W} \mathrm{~m}^{-2}$ (Table 2 ). In the western Weddell Sea, similar values $\left(7-8 \mathrm{~W} \mathrm{~m}^{-2}\right)$ to those shown here for the Bellingshausen Sea are found. In the Bellingshausen Sea, we measured average water temperature elevations of only $0.06^{\circ} \mathrm{C}$. A maximum water temperature elevation of $0.24^{\circ} \mathrm{C}$ was measured only in early December 2007 when it is likely that solar heating in the lesser ice concentration of the marginal ice zone contributed to the heat content of the surface water. This rapid increase in OHF (up to $20 \mathrm{~W} \mathrm{~m}^{-2}$ ) was also reported at the fast-ice site of Prydz Bay, East Antarctica, in mid-December 2006 and was also attributed to possible warm deep water intrusion and increased solar heating (Lei and others, 2010).

The most extreme OHF $\left(>150 \mathrm{~W} \mathrm{~m}^{-2}\right)$ measured at the end of the record reported by Morison (1995) was also associated with drift into open water. In the Amundsen Sea we measured average temperature elevation of $0.14^{\circ} \mathrm{C}$ (over twice the average value $\left(0.06^{\circ} \mathrm{C}\right)$ in the Bellingshausen Sea) and a maximum of $0.35^{\circ} \mathrm{C}$. The temperature elevations that we measured at the fast-ice site in the Amundsen Sea were of similar magnitude to that measured by Morison (1995), perhaps an indication of the existence of upwelling effects on the continental shelf in the Amundsen Sea. Similarly, a typical temperature elevation of $\sim 0.1^{\circ} \mathrm{C}$ was measured during the 1986 austral winter in the eastern Weddell Sea (Gordon and Huber, 1990), which was greater than what we measured under the pack ice in the Bellingshausen Sea and closer to what we measured under the fast ice in the Amundsen Sea.

A consistent feature between previous results in the Weddell Sea and the results of our study was the detection of short-term average surface water current speeds that were presumably due to semi-diurnal inertial/tidal oscillations (Muench and others, 2001; Sirevaag and others, 2010).

\subsection{The driving forces of $\mathrm{OHF}$}

Ocean heat flux may be constrained by both the availability of heat and the intensity of mechanical mixing at the ice/ water interface (Muench and others, 2001). In the Bellingshausen Sea, we find that water temperature elevations are not correlated with measured drift speeds. This is consistent with what was found in the Weddell Sea (Muench and others, 2001). Martinson and lannuzzi (1998) found that drift speed and surface water temperature elevation vary independently, although the average of their combined effect on $\mathrm{OHF}$ may be less variable. During summer, when there is no sea-ice freezing process to upset the density balance in the surface water, a greater proportion of OHF may be attributed to diffusion across the pycnocline (Gordon and Huber, 1990; Hohmann and others, 2002). Autumn freezing in the Amundsen Sea initiated greater convection between the deep and shallow waters (Gordon and Huber, 1990). Hence, both shallower bottom topography and seasonal freezing may have initiated greater entrainment of deep water under the fast ice in the summer/autumn transition in the Amundsen Sea as compared to beneath the spring pack ice in the Bellingshausen Sea. Consequently, turbulent stress as a means to transport heat across the pycnocline may have been more important in the Bellingshausen Sea. This is consistent with the greater drift speeds measured in the Bellingshausen Sea and the greater water temperature elevations measured in the Amundsen Sea.

The OHF in the Amundsen Sea is $\sim 17 \mathrm{~W} \mathrm{~m}^{-2}$, with the primary source of heat flux attributed to the deep-water upwelling. The deep water is also the source of heat at several hundred meters depth to the base of icebergs and the ice shelves. The surface heat flux found here would be

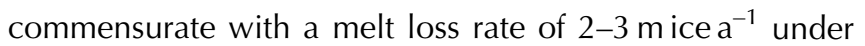
nearby icebergs and ice shelves. This melting rate is compatible with tracer estimates of the significant freshwater flux from glacial melt into the southeast Pacific sector bordering the Amundsen and Bellingshausen Seas (Jacobs and others, 1996; Jenkins and others, 1997; Hellmer and others, 1998; Hohmann and others, 2002).

\section{CONCLUSIONS}

With appropriate choice of a level ice site, we find that the time-averaged heat flux from near-surface ocean measurements of temperature, salinity and drift velocity of pack ice agrees well with the time-averaged OHF derived from independent measures of ice-melt thickness changes. This independent validation of the bulk heat transfer parameterization for the Antarctic, as well as for the Arctic done previously, therefore may be of interest to the modeling community examining ice-ocean interaction in the Antarctic. A clear limitation, however, for the ice-melt rate derived $\mathrm{OHF}\left(\mathrm{OHF}_{2}\right)$ is the assumption of near-zero 
temperature gradient near the bottom ice surface, with the result that it only works for thick snow-covered ice, not for thin snow-covered ice. Use of the ocean parameters measurement technique allows determination of shorterterm heat flux events that are probable proxies for mixedlayer processes in the near-surface ocean.

A clear difference in water condition under sea ice is found between the Bellingshausen Sea during spring and the Amundsen Sea in summer. In the Bellingshausen Sea, the overall melting process generally shows a 'well-mixed' winter mixed layer with fairly uniform temperature and salinity, down to depths $>50 \mathrm{~m}$. In the Amundsen Sea, in contrast, water stratification under fast ice is clearly seen where the colder water is found on the top of the $\sim 300 \mathrm{~m}$ water column under sea ice. A clear transition from the end of under-ice melt to the onset of ice growth, i.e. from summer shift to autumn conditions in the under-ice water regime, is also found from the data.

From the water temperature elevations observed, an OHF of $17 \pm 2 \mathrm{~W} \mathrm{~m}^{-2}$ under the fast ice is derived in the coastal Amundsen Sea. High-OHF events measured at the fast-ice site in the Amundsen Sea appear to be associated with the water temperature elevation peaks that originated from the deep water. By contrast, low OHF $\left(7-8 \mathrm{~W} \mathrm{~m}^{-2}\right)$ derived under the pack ice in the Bellingshausen Sea was associated with lesser water temperature elevations and apparently greater turbulent stress.

Our study also suggests that past deployments of thermistor strings can be reanalyzed for short-term OHF events in the Bellingshausen Sea, as well as in other areas of both polar regions where IMBs or near-surface thermistor strings have been previously deployed, without an icemoored CTD.

\section{ACKNOWLEDGEMENTS}

This work was supported by US National Science Foundation grants ANT 0703682 - Sea Ice Mass Balance in the Antarctic (principal investigator (PI) S.F. Ackley) and ANT-0839053 Sea Ice System in Antarctic Summer (PIs S.F. Ackley, H. Xie, B. Nowak), and NASA grant NNX08AQ87G - Antarctic Sea Ice from Space (PIs S.F. Ackley, H. Xie), all to the University of Texas at San Antonio (UTSA). We thank Bruce Elder (CRREL, Hanover NH) for preparing IMB equipment and data-processing templates, Cathy Geiger for real-time monitoring of Argos data transmission, and Sharon Stammerjohn and the other scientists and crew of the N.B. Palmer for deployment of equipment in the field. E.A. Tichenor acknowledges the support of UTSA's Center for Water Research (CWR) and the US Department of Agriculture's (USDA) Hispanic Leaders in Agriculture and the Environment (HLAE) program. Critical reviews and constructive comments by editors Petteri Uotila and Petra Heil and two anonymous reviewers improved the quality of the manuscript and are greatly appreciated.

\section{REFERENCES}

Ackley SF, Lewis MJ, Fritsen $\mathrm{CH}$ and Xie H (2008) Internal melting in Antarctic sea ice: development of 'gap layers'. Geophys. Res. Lett., 35(11), L11503 (doi: 10.1029/2008GL03364)

Allison I (1981) Antarctic sea ice growth and oceanic heat flux. IAHS Publ. 131 (Symposium at Canberra 1979 - Sea Level, Ice and Climatic Change), 161-170
Brandon M, Cottier FR and Nilsen F (2010) Sea ice and oceanography. In Thomas DN and Dieckmann GS eds. Sea ice. Wiley-Blackwell, Chichester, 79-112

De Steur L, Holland DM, Muench RD and McPhee MG (2007) The warm-water 'halo' around Maud Rise: properties, dynamics and impact. Deep-Sea Res. I, 54(6), 871-896 (doi: 10.1016/j. dsr.2007.03.009)

Fujino K, Lewis EL and Perkin RG (1974) The freezing point of seawater at pressures up to 100 bars. J. Geophys. Res., 79(12), 1792-1797 (doi: 10.1029/JC079i012p01792)

Geiger CA, Ackley SF and Hibler WD III (1998) Sea ice drift and deformation processes in the western Weddell Sea. In Jeffries $\mathrm{MO}$ ed. Antarctic sea ice: physical processes, interactions and variability. (Antarctic Research Series 74) American Geophysical Union, Washington, DC, 141-160

Gordon AL and Huber BA (1984) Thermohaline stratification below the Southern Ocean sea ice. J. Geophys. Res., 89(C1), 641-648 (doi: 10.1029/JC089iC01p00641)

Gordon A and Huber BA (1990) Southern Ocean winter mixed layer. J. Geophys. Res., 95(C7), 11 655-11672 (doi: 10.1029/ JC095iC07p11655)

Gordon AL and Huber BA (1995) Warm Weddell deep water west of Maud Rise. J. Geophys. Res., 100(C7), 13 747-13 753 (doi: 10.1029/95JC01361)

Heil P and 6 others (2008) Tidal forcing on sea-ice drift and deformation in the western Weddell Sea in early austral summer, 2004. Deep-Sea Res. II, 55(8-9), 943-962 (doi: 10.1016/j.dsr2.2007.12.026)

Heil P, Massom RA, Allison I, Worby AP and Lytle VI (2009) Role of off-shelf to on-shelf transitions for East Antarctic sea ice dynamics during spring 2003. J. Geophys. Res., 114(C9), C09010 (doi: 10.1029/2008JC004873)

Hellmer HH, Jacobs SS and Jenkins A (1998) Oceanic erosion of a floating Antarctic glacier in the Amundsen Sea. In Jacobs SS and Weiss RF eds. Ocean, ice and atmosphere: interactions at the Antarctic continental margin. (Antarctic Research Series 75) American Geophysical Union, Washington, DC, 83-100

Hohmann R, Schlosser P, Jacobs S, Ludin A and Weppernig R (2002) Excess helium and neon in the southeast Pacific: tracers for glacial meltwater. J. Geophys. Res., 107(C11), 3198 (doi: 10.1029/2000JC000378)

Hohmann R, Schlosser P and Huber B (2003) Helium 3 and dissolved oxygen balances in the upper waters of the Weddell Sea: implications for oceanic heat fluxes. J. Geophys. Res., 108(C3), 3087 (doi: 10.1029/2000JC000474)

Jacobs SS, Hellmer HH and Jenkins A (1996) Antarctic ice sheet melting in the southeast Pacific. Geophys. Res. Lett., 23(9), 957-960 (doi: 10.1029/96GL00723)

Jenkins A, Vaughan DG, Jacobs SS, Hellmer HH and Keys JR (1997) Glaciological and oceanographic evidence of high melt rates beneath Pine Island Glacier, West Antarctica. J. Glaciol., 43(143), 114-121

Josberger EG (1987) Bottom ablation and heat transfer coefficients from the 1983 marginal ice zone experiments. J. Geophys. Res., 92(C7), 7012-7016 (doi: 10.1029/JC092iC07p07012)

Lei R, Li Z, Cheng B, Zhang Z and Heil P (2010) Annual cycle of landfast sea ice in Prydz Bay, east Antarctica. J. Geophys. Res., 115(C2), C02006 (doi: 10.1029/2008JC005223)

Lei R, Li N, Heil P, Cheng B, Zhang Z and Sun B (2014) Multiyear sea ice thermal regimes and oceanic heat flux derived from an ice mass balance buoy in the Arctic Ocean. J. Geophys. Res., 119(1), 537-547 (doi: 10.1002/2012JC008731)

Lewis MJ and 6 others (2011) Sea ice and snow cover characteristics during the winter-spring transition in the Bellingshausen Sea: an overview of SIMBA 2007. Deep-Sea Res. II, 58(9-10), 1019-1038 (doi: 10.1016/j.dsr2.2010.10.027)

Lytle VI and Ackley SF (1996) Heat flux through sea ice in the western Weddell Sea: convective and conductive transfer processes. J. Geophys. Res., 101(C4), 8853-8868 (doi: 10.1029/95JC03675) 
Martinson DG and lannuzzi RA (1998) Antarctic ocean-ice interaction: implications from ocean bulk property distributions in the Weddell Gyre. In Jeffries MO ed. Antarctic sea ice: physical processes, interactions and variability. (Antarctic Research Series 74) American Geophysical Union, Washington, DC, 243-271

Maykut GA (1986) The surface heat and mass balance. In Untersteiner N ed. Geophysics of sea ice. (NATO ASI Series B: Physics 146) Plenum Press, London, 395-463

McPhee MG (1986) The upper ocean. In Untersteiner $\mathrm{N}$ ed. Geophysics of sea ice. (NATO ASI Series B: Physics 146) Plenum Press, London, 339-394

McPhee MG (1992) Turbulent heat flux in the upper ocean under sea ice. J. Geophys. Res., 97(C4), 5365-5379 (doi: 10.1029/ 92JC00239)

McPhee MG (2008) Physics of early summer ice/ocean exchanges in the western Weddell Sea during ISPOL. Deep-Sea Res. II, 55(8-9), 1075-1097 (doi: 10.1016/j.dsr2.2007.12.022)

McPhee MG, Maykut GA and Morison JH (1987) Dynamics and thermodynamics of the ice/upper ocean system in the marginal ice zone of the Greenland Sea. J. Geophys. Res., 92(C7), 7017-7031 (doi: 10.1029/JC092iC07p07017)

McPhee MG and 8 others (1996) The Antarctic Zone Flux Experiment. Bull. Am. Meteorol. Soc., 77(6), 1221-1232 (doi: 10.1175/1520-0477(1996)077<1221:TAZFE>2.0.CO;2)

McPhee MG, Ackley SF, Kottmeier C and Morison JH (1999) Ocean heat flux in the central Weddell Sea during winter. J. Phys. Oceanogr., 29(6), 1166-1179 (doi: 10.1175/1520-0485(1999) $029<1166$ :OHFITC $>2.0 . \mathrm{CO} ; 2)$

Morison JH (1995) Autonomous vehicle and hydrographic buoy measurements during ANZFLUX. Antarct. J. US, 30, 106-108

Morison JH, McPhee MG and Maykut GA (1987) Boundary layer, upper ocean, and ice observations in the Greenland Sea marginal ice zone. J. Geophys. Res., 92(C7), 6987-7011 (doi: 10.1029/JC092iC07p06987)

Muench RD and 6 others (2001) Maud Rise revisited. J. Geophys. Res., 106(C2), 2423-2440 (doi: 10.1029/2000JC000531)

Omstedt A and Wettlaufer JS (1992) Ice growth and oceanic heat flux: models and measurements. J. Geophys. Res., 97(C6), 9383-9390 (doi: 10.1029/92JC00815)

Ono N (1968) Thermal properties of sea ice, IV. Thermal constants of sea ice. Low Temp. Sci., Ser. A 26 , 329-349 [in Japanese]

Padman L, Fricker HA, Coleman R, Howard S and Erofeeva L (2002) A new tide model for the Antarctic ice shelves and seas. Ann. Glaciol., 34, 247-254 (doi: 10.3189/172756402781817752)
Perovich DK and 7 others (2004) Winter sea-ice properties in Marguerite Bay, Antarctica. Deep-Sea Res. II, 51(17-19), 2023-2039 (doi: 10.1016/j.dsr2.2004.07.024)

Perovich DK, Light B, Eicken H, Jones KF, Runciman K and Nghiem SV (2007) Increasing solar heating of the Arctic Ocean and adjacent seas, 1979-2005: attribution and role in the ice-albedo feedback. Geophys. Res. Lett., 34(19), L19505 (doi: 10.1029/ 2007GL031480)

Sirevaag A, McPhee MG, Morison JH, Shaw WJ and Stanton TP (2010) Wintertime mixed layer measurements at Maud Rise, Weddell Sea. J. Geophys. Res., 115(C2), C02009 (doi: 10.1029/ 2008JC005141)

Toole JM, Krishfield RA, Timmermans M-L and Proshutinsky A (2011) The ice-tethered profiler: Argo of the Arctic. Oceanography, 24(3), 126-135 (doi: 10.5670/oceanog. 2011.64)

Wang $C$ and 7 others (2013) Spring sea-ice evolution in Rijpfjorden $\left(80^{\circ} \mathrm{N}\right)$, Svalbard, from in situ measurements and ice massbalance buoy (IMB) data. Ann. Glaciol., 54(62 Pt 2), 253-260 (doi: 10.3189/2013AoG62A135)

Weeks WF and Ackley SF (1986) The growth, structure, and properties of sea ice. In Untersteiner $\mathrm{N}$ ed. Geophysics of sea ice. (NATO ASI Series B: Physics 146) Plenum Press, London, 9-164

Wettlaufer JS (1991) Heat flux at the ice-ocean interface. J. Geophys. Res., 96(C4), 7215-7236 (doi: 10.1029/90JC00081)

Wettlaufer JS, Untersteiner $N$ and Colony $R$ (1990) Estimating oceanic heat flux from sea-ice thickness and temperature data. Ann. Glaciol., 14, 315-318

Worby AP, Massom RA, Allison I, Lytle VI and Heil P (1998) East Antarctic sea ice: a review of its structure, properties and drift. In Jeffries MO ed. Antarctic sea ice: physical processes, interactions and variability. (Antarctic Research Series 74) American Geophysical Union, Washington, DC, 41-67

Xie $\mathrm{H}$ and 7 others (2011) Sea-ice thickness distribution of the Bellingshausen Sea from surface measurements and ICESat altimetry. Deep-Sea Res. II, 58(9-10), 1039-1051 (doi: 10.1016/ j.dsr2.2010.10.038)

Xie $\mathrm{H}$ and 6 others (2013) Summer sea ice characteristics and morphology in the Pacific Arctic sector as observed during the CHINARE 2010 cruise. Cryosphere, 7(4), 1057-1072 (doi: 10.5194/tc-7-1057-2013)

Yen YC (1981) Review of thermal properties of snow, ice and sea ice. CRREL Res. Rep. 81-10 